\title{
New Developments In Commercial Freedom Of Speech
}

Martin A. Goldberg, University of New Haven, USA

\begin{abstract}
The last few years have seen several U. S. Supreme Court cases redefining the scope of freespeech rights, particularly those of businesses. These cases have widespread ramifications for a multitude of areas of business law, such as political speech, government regulation of media, and corporate liability for defamation.
\end{abstract}

Keywords: Corporate; Commercial; Free Speech; Freedom of Speech

\section{INTRODUCTION}

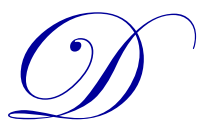

oes the United States Supreme Court today have an expansive view of the free-speech protection granted by the First Amendment or a restrictive view? High-profile cases such as Citizens United, ${ }^{1}$ giving corporations free-speech parity with individuals and equating monetary expenditures with speech, and Stevens, ${ }^{2}$ granting free-speech protection to the dissemination of videos depicting cruelty to animals, have created an impression that this Court is decidedly on the side of freedom of speech.

However, this view has had skeptics. ${ }^{3}$ A survey of some recent holdings bears witness to the losses of free-speech claimants:

- $\quad$ Speech by a government employee, as part of his official duties, is not protected by the First Amendment. In Garcetti v. Ceballos, ${ }^{4}$ the Supreme Court distinguished between speech by public employees in their capacity as citizens as opposed to speech in an official capacity. In a claim by the respondent that his freedom of speech was violated when there were retaliatory actions taken against him for whistle-blowing, the Court held that statements in his official capacity were not protected by the First Amendment.

- $\quad$ Depriving a prisoner of written materials, such as newspapers, is not a free-speech violation. In Beard $v$. Banks ${ }^{5}$ the Court held that use of such techniques in order to maintain order in a prison was a legitimate use of government power.

- $\quad$ Disciplining a student for displaying, at a school event, a banner perceived by a principal as advocating illegal drug use was not a violation of the student's freedom of speech. In Morse v. Frederick, ${ }^{6}$ students unfurled a banner with the message "Bong Hits 4 Jesus," which may have had no particular meaning at all, but which the principal could legitimately ban as promoting drug use.

- Individuals advising terrorist groups on humanitarian and legal means for resolving their issues may be prosecuted for providing support to terrorist organizations. The case of Holder v. Humanitarian Law Project ${ }^{7}$ involved the prosecution of criminal defendants under federal law that prohibited the providing of

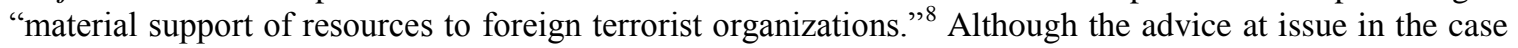

${ }^{1}$ Citizens United v. FEC, 558 U.S. 310 (2010).

${ }^{2}$ U.S. v. Stevens, 559 U.S. _ (2010).

${ }^{3}$ A summary of criticisms can be found at Adam Liptak, "Study Challenges Supreme Court's Image as Defender of Free Speech," The New York Times, January 7, 2012, http://www.nytimes.com/2012/01/08/us/study-challenges-supreme-courts-image-as-defender-of-freespeech.html.

${ }^{4}$ Garcetti v. Ceballos, 547 U.S. 410 (2006).

${ }^{5}$ Beard v. Banks, 548 U.S. 521 (2006).

${ }^{6}$ Morse v. Frederick, 551 U.S. 393 (2007).

${ }^{7}$ Holder v. Humanitarian Law Project, 561 U.S.

818 U.S.C. $\$ 2339 \mathrm{~B}$. (2010). 
was not itself support for terrorism, and could be regarded as intending to deter terrorism, the advice was still held to be support for terrorist groups and not protected under the First Amendment.

The pioneering critic of the view of the Roberts Court as a champion of free speech, Erwin Chemerinsky of University of California, Irvine, Law school, has noted with regard to Citizens United and a case involving monetary limits on campaign contributions, that "decisions of the Roberts Court suggest that what really animates its decisions is a hostility to campaign finance laws much more than a commitment to expanding speech."

This paper will look at the issue from a somewhat different perspective. Instead of focusing on campaign finance laws predominantly, this paper will look at the free speech cases that have their greatest relevance to business enterprises rather than individuals. In fact, the cases with the most egregious losses for freedom of speech invariably involve individuals and the success rate of businesses is much higher.

Rather than asking whether the Court is for or against free speech, it might be more instructive to look at the situations under which the free-speech position has prevailed and the situations where it has not prevailed. This paper analyzes the cases with a view towards shedding light on three questions: (1) What are the different situations where free-speech issues arise, in particular those relevant to business enterprises? (2) Are there overarching principles that can provide a unified explanation of a wide range of cases involving freedom of speech by business enterprises? (3) What are the practical steps that may be taken by business enterprises to avail themselves of the principles of these cases, in order to use free-speech protection to reduce the possibility of criminal or civil liability for actions that have a speech component?

In analyzing these questions, we will necessarily look at the high-profile cases such as Citizens United. However, these cases will be looked at in a broader context of numerous cases decided by the Supreme Court, both recent cases and their historical antecedents.

\section{CORPORATE POLITICAL SPEECH FROM BUCKLEY AND BELLOTTI TO CITIZENS UNITED}

The basis of the modern Court's concept of corporate free speech can be found decades earlier in two key cases - Buckley v. Valeo ${ }^{10}$ and First National Bank of Boston v. Bellotti. ${ }^{11}$

Buckley addressed campaign contribution limits in the Federal Election Campaign Act Amendments of 1974 (FECA), with a two-part conclusion. Limits on contributions to candidates were held to be Constitutional, but limits on independent expenditures were not. This case did not address the question of the rights of corporations and unions and, in fact, bans on these expenditures were recodified by Congress after Buckley. ${ }^{12}$

The Bellotti case more clearly addressed the question of corporate free-speech rights. That case held unconstitutional a Massachusetts law that imposed criminal penalties on a corporation that made contributions or expenditures to influence any public vote, other than one materially affecting the corporation itself.

Bellotti was first in a line of string citations used by the Citizens United majority opinion to support the notion that "The Court has recognized that First Amendment protection extends to corporations." ${ }^{13}$ Missing from that overarching statement is an indication of whether these cases extended partial First Amendment protection to corporations or complete, total, plenary First Amendment protection to corporations equivalent to that which would be afforded to an individual.

Bellotti itself was circumspect in the extent of First Amendment protection granted to corporations.

\footnotetext{
${ }^{9}$ Erwin Chemerinsky, "Not a Free Speech Court,” Arizona Law Review, Vol. 53, page 723 (2011).

${ }^{10}$ Buckley v. Valeo, 424 U.S. 1 (1976).

${ }^{11}$ First National Bank of Boston v. Bellotti, 435 U.S. 765 (1978).

122 U.S.C. $\$ 441 b$.

${ }^{13}$ Citizens United v. FEC, 558 U.S. 310 (2010). slip op. page 25.
} 
The First Amendment, in particular, serves significant societal interests. The proper question, therefore, is not whether corporations "have" First Amendment rights and, if so, whether they are coextensive with those of natural persons. Instead, the question must be whether [the Massachusetts law] abridges expression that the First Amendment was meant to protect. ${ }^{14}$

The Court held that the type of communication involved, influencing the outcome of a vote, was protected by the First Amendment. However, the Court expressly declined to grant to corporations the same First Amendment protection as that possessed by individuals.

The Court in Citizens United could have reached the same conclusion as Bellotti, using the same reasoning. If that had happened, the case would still be controversial from a political point of view, but it would not have had the broad impact on business law, in general. Instead, Citizens United, though citing Bellotti, did what Bellotti refused to do, which is to grant full First Amendment rights to corporations as though they were natural persons.

\section{COMMERCIAL FREE SPEECH}

While political speech receives special protection, this does not mean that ordinary commercial activity motivated primarily or exclusively by profit - does not receive First Amendment protection. In the recent case of U.S. v. Stevens, 559 U.S. _ ${ }^{15}$ the Court held unconstitutional a federal statute criminalizing creation or sale of depictions of the intentional maiming, torture, mutilation, or killing of a living animal if the acts depicted were illegal where the depiction was created or sold.

In making its ruling on the specific issue involved, the Supreme Court set forth a broader rule; that is, that First Amendment freedom of speech had certain historic exceptions, specifically obscenity, incitement, and socalled fighting words. The Court's opinion expressed a reluctance to create new exceptions.

In Brown v. Entertainment Merchants Association, ${ }^{16}$ the Court protected commercial free speech in another context. That case examined a California law banning the sale of violent video games to individuals under the age of 18 and also required that they be labeled " $18 . "$

While seemingly based on an uneventful rehashing of the holdings of prior cases, in fact, Brown advanced a fairly revolutionary notion that "underinclusiveness" could be a reason to find a statute violative of First Amendment freedom of speech. While ordinarily a free-speech claim challenges a law as being overly inclusive, Brown takes this a step further.

Underinclusiveness raises serious doubts about whether the government is, in fact, pursuing the interest it invokes rather than disfavoring a particular speaker or viewpoint. See City of Ladue v. Gilleo, 512 U.S. 43, 51 (1994); Florida Star v. B.J.F, 491 U.S. 524, 540 (1989). Here, California has singled out the purveyors of video games for disfavored treatment - at least when compared to booksellers, cartoonists, and movie producers - and has given no persuasive reason why. ${ }^{17}$

In order to understand how far the Brown case advanced the underinclusiveness principle, it is helpful to look more closely at the two prior Supreme Court cases cited by Brown in support of the principle. One of them City of Ladue v. Gilleo ${ }^{18}$ involved a town ordinance that banned law signs but created certain exceptions. Margaret P. Gilleo was a homeowner who wanted to post a sign protesting the Gulf War, but this kind of sign wasn't permitted as one of the exceptions. The Court took issue with the selectivity of the messages permissible in lawn signs.

\footnotetext{
${ }^{14} 435$ U.S. $765,776$.

${ }^{15}$ U.S. v. Stevens, 559 U.S. _ (2010).

${ }^{16}$ Brown v. Entertainment Merchants Association, 564 U.S. __ (2010).

${ }^{17}$ Id., slip op. page 14.

${ }^{18}$ City of Ladue v. Gilleo, 512 U.S. 43 (1994).
}

2013 The Clute Institute $\quad$ Copyright by author(s) $\underline{\text { Creative Commons License CC-BY }}$ 
While surprising at first glance, the notion that a regulation of speech may be impermissibly underinclusive is firmly grounded in basic First Amendment principles. [A footnote here indicates that distinctions among different kinds of speech may also violate the Equal Protection Clause, but does not support the premise itself.] Thus, an exemption from an otherwise permissible regulation of speech may represent a governmental "attempt to give one side of a debatable public question an advantage in expressing its views to the people. (First Nat. Bank of Boston v. Belloti [sic], 435 U.S. $765,785-786(1978)){ }^{19}$

Florida Star v. B.J.F. ${ }^{20}$ is another case cited by the Court in Brown to support its invocation of the "underinclusiveness" doctrine. That case examined a Florida statute making it unlawful to "print, publish, or broadcast, or cause or allow to be printed, published, or broadcast, in any instrument of mass communication the name, address, or other identifying fact or information of the victim of any sexual offense..." The Court took issue with the fact that the statute focused only on dissemination of this information by an "instrument of mass communication" and not by other means. The Court said that to demonstrate its commitment to protecting the privacy of sexual assault victims, the prohibition would have to apply to "the small-time disseminator as well as the media giant.",21

The Brown Court charges these two cases with carrying a greater load than they seem to be able to carry. In City of Ladue, while the ordinance is criticized as being underinclusive, the substance of the criticism is that is it a content-based restriction on speech. Florida Star comes closer to standing for the underinclusiveness principle as invoked by Brown, but it still doesn't extend as far as the Brown Court would take it. While City of Ladue is about content-based underinclusiveness and Florida Star is about speaker-based and media-based underinclusiveness, neither goes as far as Brown to say that media-based underinclusiveness could, by itself, be a violation of the First Amendment. Thus, Brown has, without much fanfare, developed what substantially is a new argument that can be made in a claim that a particular law violates the free-speech protections of the First Amendment.

In Fox Television Stations, Inc. v. FCC, ${ }^{22}$ the Second Circuit held that the policy of the Federal Communications Commission penalizing broadcasters for "fleeting expletives" "violates the First Amendment because it is unconstitutionally vague, creating a chilling effect that goes far beyond the fleeting expletives at issue here." 23

An amicus brief in the current appeal before the Supreme Court presses for the applicability of the underinclusiveness doctrine:

As recently as last term, the Court emphasized that even legitimate government aims, when burdening First Amendment Rights, "must be pursued by means that are neither seriously underinclusive nor seriously overinclusive." Brown v. Entm't Merch. Ass'n, 131 S. Ct. 2729, 2741-42 (2011) $)^{24}$

The gravamen of the brief was that FCC rules applicable to broadcast media were fatally underinclusive in that they could not apply to non-broadcast media

Unfortunately, the U.S. Supreme Court never addressed the merits of this argument, instead ruling against FCC solely on the basis of the fact that its regulations did not give broadcasters fair notice.

While the success of this argument is yet to be determined in this particular type of case, Brown has assured its place in free-speech jurisprudence and debate. Effectively, the historical rule that content-based restrictions are subject to strict scrutiny has now been expanded by the underinclusiveness principle to mean that the same strict scrutiny will apply to any distinction made by the law, and this is wholly consistent with the Citizens United holding that the speaker's identity (in that case, corporate identity) cannot be the basis of a free-speech restriction. While the

${ }^{19}$ Id., at page 51 .

${ }^{20}$ Florida Star v. B.J.F., 491 U.S. 524 (1989).

${ }^{21}$ Id., at page 540 .

${ }^{22}$ Fox Television Stations, Inc. v. FCC, 613 F.3d 317 (2d Cir. 2010).

${ }^{23} \mathrm{Id}$.

${ }^{24}$ Brief for Amici Curiae Former FCC officials in Support of Respondents, page 15.

278 Copyright by author(s) $\underline{\text { Creative Commons License CC-BY }}$

2013 The Clute Institute 
opinion in Citizens United did not flesh out the underinclusiveness principle, as well as the Brown case which came later, its position is entirely consistent with it. And the trend in the development of this principle points to broadening the virtual prohibition on content-based restrictions, so that it applies to restrictions based on both the type of media used for the communications as well as to the identity of the speaker.

\section{PROTECTION FROM LIABILITY FOR DEFAMATION-RELATED TORTS}

Several torts established under common law or state statute have overlapping elements and often find themselves arising out of the same fact pattern. For instance, an employee suing for wrongful discharge may also allege claims against the defendant's former employer (and perhaps its managers) for defamation, intentional infliction of emotional distress, negligent infliction of emotional distress, and tortuous interference (i.e., the manager's' interference with the employee's relationship with the employer).

Although New York Times Co. v. Sullivan ${ }^{25}$ was the landmark case in introducing Constitutional limits on defamation lawsuits, it was left for later cases, such as Hustler Magazine, Inc. v. Falwell ${ }^{26}$ to establish that the limits applied as well to intentional infliction of emotional distress. It is not disputed now that anything in the cluster of defamation-related torts might find itself tested under the First Amendment.

Snyder v. Phelps,${ }^{27}$ the infamous case of the picketing of a soldier's funeral by the Westboro Baptist Church, was an example of such a cluster of claims. There, five state tort law claims were alleged - defamation, publicity given to private life, intentional infliction of emotional distress, intrusion on seclusion, and civil conspiracy. ${ }^{28}$ This was not strictly a case involving a business enterprise. In fact, it may be fair to say this truly was an association of individuals - a small one in fact - with a personal rather than a business agenda. Yet, the long-term beneficiaries of the case may well be businesses which often find themselves the subject of suits for such defamation-related torts.

In the Snyder case, the District Court dismissed the counts in defamation and publicity given to private life and, after remitting punitive damages, awarded the soldier's father $\$ 2.9$ million in compensatory damages and $\$ 2.1$ million in punitive damages. This result was overturned by the Fourth Circuit as being a violation of the First Amendment freedom of speech rights of the defendant.

The majority opinion by the U. S. Supreme Court, written by Chief Justice Roberts, focused its decision on the issue of public concern: "Whether the First Amendment prohibits holding Westboro liable for its speech, in this case, turns largely on whether that speech is of public or private concern, as determined by all the circumstances of the case." 29

The Court cited only two cases where it had held speech not to be of public concern - disclosure of a particular individual's credit report, Dun \& Bradstreet, Inc. v. Greenmoss Builders, Inc., ${ }^{30}$ and sexually explicit videos in San Diego v. Roe. ${ }^{31}$ While acknowledging that "the boundaries of the public concern test are not well defined" (quoting San Diego v. Roe, at page 83), the Court held, with the majority of cases, that under the facts at issue, the speech did involve matters of public concern. In essence, as the form of the speech was political opinion (in this case, that the United States was being punished by God for its tolerance of homosexuality), the speech was accorded the same protection as speech whose content was related to public discourse.

Putting this another way, a combination of public and private speech apparently rendered all the speech protected as public concern. "And even if a few of the signs - such as "You're Going to Hell" and "God Hates You" - were viewed as containing messages related to Matthew Snyder or the Snyders specifically, that would not change

\footnotetext{
${ }^{25}$ New York Times Co. v. Sullivan, 376 U.S. 254 (1964).

${ }^{26}$ Hustler Magazine, Inc. v. Falwell, 485 U.S. 46 (1988).

${ }^{27}$ Snyder v. Phelps, 562 U.S. _ (2011).

${ }^{28}$ Id., slip op. page 3.

${ }^{29}$ Id., slip op. page 5.

${ }^{30}$ Dun \& Bradstreet, Inc. v. Greenmoss Builders, Inc., 472 U.S. 749 (1985).

${ }^{31}$ San Diego v. Roe, 543 U.S. 77 (2004).
} 
the fact that the overall thrust and dominant theme of Westboro's demonstration spoke to broader public issues. ${ }^{32}$

Two additional points warrant mention. First, the majority opinion stresses the fact that Westboro Church had numerous prior demonstrations at military funerals, as evidence that its speech was not directed at the Snyder family. As pointed out in the dissent by Justice Alito, this did not change the nature of the injury. Second, also pointed out by the dissent, the Hustler case may have given First Amendment protection to the defendant in an intentional infliction of emotional distress claim, but in that case, the plaintiff was a public figure.

The dissent also focused on the nature of intentional infliction of emotional distress and the extent of the injury required under common law and state laws in order to sustain such a claim. Given the similarity of intentional infliction of emotional distress with intentional physical injury, the question is raised - but not answered as to whether all tortious conduct is protected if within the context of publicizing a political message.

In other words, a corporation such as a newspaper routinely involved in scrutinizing individuals in the news should be immunized from defamation-related claims because, as with the Westboro Baptist Church, it was just doing its job. The same would apply to a corporation routinely discharging employees wrongfully or breaching contracts. Given the fact that it is rare for a small group of individuals to maintain ongoing behavior, such as that of Westboro Baptist Church, but common for a business enterprise, that case has more relevance for businesses than for individuals.

As of this writing, there is a case winding its way through the courts - the case Shirley Sherrod against the estate of political commentator Andrew Breitbart. The substance of that case was that the editing of video footage of Sherrod falsely created the impression that she was a racist. Under the principle applied in Snyder, the fact that Breitbart (1) had a history of personal attacks on individuals and (2) made his communications within a broader context of championing politically conservative causes should give him more First Amendment protection than if this were an isolated case.

\section{COPYRIGHT PROTECTION VS. FREE SPEECH}

As with the laws of defamation and related torts, copyright law is also a situation where there is a balancing of interests between competing legitimate interests. As a basic principle, the copyright owned by one person is a legally-enforceable restriction on the speech of another person. This is no dispute or controversy about this basic principle. The balancing of the free-speech rights is accomplished by the fact that the copyright is for a limited time, similar to the limited-time grant of rights with patents. As stated in Article I, section 8 of the Constitution, where powers are granted to the Congress, included in clause 8 is the power - "To promote the Progress of Science and useful Arts, by securing for limited Times to Authors and Inventors the exclusive Right to their respective Writings and Discoveries".

Interpretation of this clause comes before the Supreme Court when there has been a change in the amount of time "limited."

An earlier case defined the nature of the issue. In Eldred v. Ashcroft , $^{33}$ the Court addressed the constitutionality of the 1998 Sonny Bono Copyright Term Extension Act, ${ }^{34}$ which granted to copyrights of works published before 1978 a 20-year extension of the terms previously set by the Copyright Act of 1976. Generally, the previous copyright termination 50 years after the author's death was extended 70 years after the author's death. For anyone counting, the copyright on "I Got You Babe" would have expired on January 5, 2048, but under the new law expires January 5, 2068. Copyrights originally owned by corporations (such as those made as work by hire) or of anonymous/pseudonymous authorship, were extended from 75 years from publication to 95 years after publication, but not more than 120 years after creation of the work. ${ }^{35}$

\footnotetext{
32 Snyder v. Phelps, 562 U.S. __ (2011), slip op. page 8.

${ }^{33}$ Eldred v. Ashcroft, 537 U.S. 186 (2003).

34 Public Law 105-298, October 27, 1998.

3517 USC $\$ 302$.
} 
More recently, in Golan v. Holder ${ }^{36}$ the Court dealt with the more complex issue of retrieving from the public domain works whose copyrights had expired in the United States but were still protected in other nations. Lawrence Golan is a conductor and the cost of sheet music for copyrighted works is significantly more than the cost of sheet music for works in the public domain. He and similarly-situated conductors and users of works in the public domain had been reeling after Eldred, but Eldred only extended the copyright terms of works that had not yet entered the public domain. The Golan Court addressed a different issue, which was a law that took works already in the public domain and retroactively granted them copyright protection.

Thus, while Golan involved the key issue of Eldred, which was the meaning of "limited times", Golan went further. There were property issues in that once a work had passed into the public domain, in a sense it belonged to everyone, and there was also a First Amendment freedom of speech issue.

Although the U.S. attorney general was the lead respondent in this case, in fact this case differs from many other situations where freedom of speech is an issue, in that such cases ordinarily pit a speaker against the government, where in this case the issue pits the claim of a speaker against the owner of a copyright. While both sides have legally-protectable rights, the side that prevailed was the side that would more likely be associated with a business enterprise, the owner of the copyright. Thus, even though this was a case where the free-speech claimant lost, it's instructive to focus also on who the winner was, which is the side that represented corporate interests.

\section{CONCLUSION}

A host of recent cases involving freedom of speech by corporate entities and other commercial enterprises have helped define a new era for corporate freedom of speech. In addition to developing new rules for where speech will or will not be protected, the cases lay out a protocol that may be used by business enterprises to increase the likelihood that any defense based on an invocation of freedom of speech will prevail; thus:

Political Speech: While political speech has always received the greatest of protection, recent cases expand the notion of what may qualify as political speech. Thus, if an organization has a political agenda, even speech at the fringes of that agenda may be entitled to the same level of protection as purely political debate.

Government Regulation Of Media: The under-inclusiveness doctrine, now brought to center stage, will make it easier for a free-speech claimant to argue successfully that a particular law is unconstitutional.

Corporate Liability For Defamation And Related Torts: We now will look into the history of the speaker to ascertain whether there was a personal animosity against the object of the defamation or related tort. A business concerned with possible claims against it can almost immunize itself against such claims or increase the likelihood of a successful defense by creating a track record of such defamation or related torts that can be used to argue against the existence of personal animosity.

In all cases, this is a new era for corporate freedom of speech, one that goes far beyond the holding of any individual case, such as Citizens United. The rulings provide guidelines as to how a business may conduct itself in a manner to increase the likelihood of prevailing in a case where freedom of speech is an issue.

\section{AUTHOR INFORMATION}

Martin A. Goldberg, J.D., LL.M., Associate Professor, University of New Haven College of Business Department of Accounting and Law, 300 Boston Post Road, West Haven, CT 06516. Contact author: Martin A. Goldberg, mgoldberg@newhaven.edu 
NOTES 